ISSN 2080-1653

DOI 10.24917/20801653.322.21

\author{
BARBARA KOWALCZYK \\ Ośrodek Przetwarzania Informacji - Państwowy Instytut Badawczy, Warszawa, Polska \\ MARCIN OLSZEWSKI \\ Uniwersytet Ekonomiczny w Poznaniu, Polska
}

\title{
Znaczenie relacii z klientami w działalności innowacyjnej przedsiębiorstw hotelarskich
}

\section{The Role of Relations with Customers in the Innovative Activities of Hotel Companies}

Streszczenie: Przedsiębiorstwa, nawet te najmniejsze, znajdują się obecnie pod silną presją wdrażania innowacji, postrzeganych jako jeden z kluczowych czynników funkcjonowania i rozwoju firmy. Ze względu na immanentne cechy przedsiębiorstw hotelarskich wiedza pochodząca z relacji z klientami może odgrywać istotną rolę w ich działalności innowacyjnej. Artykuł ma na celu identyfikację znaczenia relacji z klientami w działalności innowacyjnej przedsiębiorstw hotelarskich w Polsce. Przybliżono w nim pojęcie innowacji pochodzących od klienta (User-Driven Innovation), a także zaprezentowano aktualny stan badań nad tym zagadnieniem w odniesieniu do podmiotów gospodarki turystycznej, a szczególnie przedsiębiorstw hotelarskich. Kluczową część artykułu stanowią wyniki badania empirycznego prowadzonego w 400 losowo wybranych hotelach $\mathrm{w}$ Polsce. Z badania wynika, że relacje z klientami mają istotne znaczenie $\mathrm{w}$ działalności innowacyjnej przedsiębiorstw. Dodatkowo przedstawione zostały podstawowe źródła innowacji, a także sposoby zaangażowania klientów $\mathrm{w}$ działalność innowacyjną. $\mathrm{Z}$ badania wynika, że ważną rolę w pozyskiwaniu i wykorzystaniu wiedzy pochodzącej od klientów odgrywają pracownicy, którzy bezpośrednio kontaktują się z gośćmi. Ponadto ustalono, że polskie hotele są jeszcze na wczesnym etapie procesu adaptacji koncepcji innowacji pochodzących od klienta. Wykorzystanie wiedzy od klienta w działalności innowacyjnej wymaga intensyfikacji działań w zakresie zarządzania wiedzą i zarządzania kadrami.

\begin{abstract}
Nowadays enterprises, including the smallest ones, are facing strong pressure of implementing innovative solutions, which are regarded as one of the key factors of the companies' performance and development. Due to the immanent characteristics of hotel enterprises, knowledge derived from customers' relations can play an important role in their innovation activities. The purpose of the article is to identify the importance of relations with customers in the innovative activities of hotel enterprises in Poland. The article presents the concept of User-Driven Innovation, as well as the current state of research on this issue in the tourism industry, particularly in hotel enterprises. The results of an empirical study conducted among 400 randomly selected hotels in Poland, are the key part of the article. According to the survey, customers' relations play great role in the innovative activities of hotel enterprises. In addition, the main sources of innovations, as well as the scope of customer engagement in innovative activities are presented. Employees who directly contact the guests have a key role in acquiring and utilising knowledge coming from customers. The survey shows that Polish hotels are still at an early stage of adapting the concept of user-driven innovations. Moreover, the utilisation of knowledge from the clients for innovations requires intensification of the activities in the field of knowledge, as well as human resources management.
\end{abstract}


Słowa kluczowe: innowacje otwarte; przedsiębiorstwa hotelarskie; relacje; user-driven innovation Key words: hotel companies; open innovations; relations; user-driven innovation

Otrzymano: 19 grudnia 2017

Received: 19 December 2017

Zaakceptowano: 15 maja 2018

Accepted: 15 May 2018

\section{Sugerowana cytacja / Suggested citation:}

Kowalczyk, B., Olszewski, M. (2018). Znaczenie relacji z klientami w działalności innowacyjnej przedsiębiorstw hotelarskich. Prace Komisji Geografii Przemysłu Polskiego Towarzystwa Geograficznego, 32(2), 299-310. https://doi.org/10.24917/20801653.322.21

\section{WSTĘP}

Zmiany w strukturze gospodarki są efektem procesów dostosowawczych, które następują głównie poprzez wdrażanie innowacji. Źródłem innowacji w gospodarce jest wiedza (OECD, 1996). W tradycyjnych modelach procesu innowacyjnego pochodzi ona przede wszystkim z wnętrza organizacji, np. z działów badawczych. Jednak w turbulentnym otoczeniu coraz większego znaczenia nabierają zewnętrzne źródła informacji pozyskiwane od klientów i kooperantów. Dotychczasowe badania potwierdzają rosnącą rolę klientów w działalności innowacyjnej przedsiębiorstw (Von Hippel, 1990; Von Hippel, 2005; Salter, Laursen, 2006; Piller, Ihl, 2009). Te prawidłowości zaobserwowano także w odniesieniu do podmiotów gospodarki turystycznej (Hjalager, Nordin, 2011), w tym przedsiębiorstw hotelarskich (Sundbo, Orfila-Sintes, Sørensen, 2007). Wzrost znaczenia zewnętrznych źródeł wiedzy pozwolił na sformułowanie nowego podejścia do innowacji znajdującego wyraz w nurcie otwartych innowacji i koncepcji innowacji pochodzących od klientów (user-driven innovation, UDI). Coraz większa koncentracja przedsiębiorstwa na potrzebach i wymaganiach klienta sprawia, że przestaje on być uczestnikiem transakcji kupna-sprzedaży, a staje się podmiotem kształtującym ofertę i mającym swój udział w tworzeniu innowacji. Celem artykułu jest identyfikacja znaczenia relacji z klientami w działalności innowacyjnej przedsiębiorstw hotelarskich w Polsce.

Artykuł składa się z trzech części poprzedzonych wstępem. W pierwszej z nich omówiono znaczenie relacji z klientami w oparciu o koncepcję innowacji pochodzących od klienta (UDI), zidentyfikowano cechy mające wpływ na implementację koncepcji UDI w przedsiębiorstwach hotelarskich, a także przedstawiono wyniki dotychczasowych badań nad tym zagadnieniem. W drugiej części przybliżono metodykę i wyniki ogólnopolskiego badania przeprowadzonego pod koniec 2015 roku wśród 400 przedsiębiorstw hotelarskich. Trzecia część, zakończenie, zawiera podsumowanie rozważań oraz propozycję kierunków dalszych prac badawczych.

\section{RELACJE Z KLIENTAMI I ICH ZNACZENIE W DZIAŁALNOŚCI INNOWACYJNEJ - KONCEPCJA INNOWACJI POCHODZĄCYCH OD KLIENTÓW (USER-DRIVEN INNOVATION, UDI)}

Innowacje są elementem szerszego procesu, w który zaangażowane jest przedsiębiorstwo budujące przewagę konkurencyjną na rynku. Wynikają one m.in. z otwartości przedsiębiorstw na nowości oraz z dążenia do doskonałości i nieustannej poprawy 
jakości oferowanych dóbr i usług. Firmy poszukujące nowych źródeł innowacji coraz częściej otwierają się na pozyskiwanie informacji z zewnątrz. E. von Hippel (1988) wskazuje na cztery podstawowe zewnętrzne źródła informacji, które mogą być wykorzystywane w działalności innowacyjnej przedsiębiorstw. Są nimi: klienci, konkurenci, dostawcy i uczelnie. Według A.M. Hjalager i S. Nordin (2011), aktywna wymiana idei i zasobów z partnerami zewnętrznymi może przyspieszyć proces uczenia się w firmie, zwiększyć zdolności innowacyjne i w efekcie podnieść jej konkurencyjność. Ponadto przedsiębiorstwa podejmujące współpracę z podmiotami z ich otoczenia w zakresie działalności innowacyjnej częściej wdrażają nowe na rynku i znaczące rozwiązania niż przedsiębiorstwa, które koncentrują się na wewnętrznych źródłach innowacji (Tether, 2002).

Istotnym zewnętrznym źródłem wiedzy dla przedsiębiorstw są tak zwani użytkownicy. E. von Hippel (2005) definiuje ich jako indywidualnych konsumentów lub firmy oczekujące wymiernych korzyści z zastosowania (użycia) określonego produktu czy usługi. Relacje i aktywna komunikacja z użytkownikami mogą być wykorzystywane w celu wdrażania nowych produktów i usług. Otwarte podejście do innowacji i zastosowanie wiedzy użytkowników, aby wprowadzić nowe produkty, usługi lub rozwiązania, które opierają się na prawdziwym zrozumieniu potrzeb nabywców oraz systematycznym angażowaniu ich w rozwój przedsiębiorstwa, charakteryzuje koncepcję user-driven innovation, UDI (Wise, Høgenhaven, 2008). A.M. Hjalager i S. Nordin (2011) definiują innowacje pochodzące od klienta jako zjawisko, w którym nowe produkty, usługi, procesy oraz zmiany o charakterze organizacyjnym i marketingowym są inspirowane potrzebami, pomysłami i opiniami użytkowników produktu. Rosnące znaczenie wiedzy użytkowników wykorzystywanej w celu rozwoju produktów jako pierwszy zauważył wspomniany E. von Hippel (1976). Ustalił on, że ta grupa osób szybciej niż inne dostrzega potrzebę udoskonalania rozwiązań lub wprowadzania nowych, wnoszących nowe wartości. Co więcej, jak podkreśla S.B. Tether (2002), jest także cennym źródłem informacji potrzebnych do identyfikowania trendów rynkowych oraz rynkowych szans.

Zapotrzebowanie na informacje pochodzące od klientów różni się w zależności od poziomu, na jakim dokonywane są zmiany w obrębie produktu lub usługi. Zaangażowanie nabywców w realizację poszczególnych etapów procesu innowacyjnego pozwala na klasyfikację użytkowników w następujący sposób (Fuller, Matzler, 2007; 0’Hern, Rindfleisch, 2008):

- etap powstawania pomysłów; do zewnętrznych źródeł informacji zaliczani są użytkownicy określani jako wiodący, projektanci, inżynierowie oraz inni użytkownicy, których sugestie uwzględnia się w procesach innowacyjnych przedsiębiorstwa;

- etap rozwoju pomysłu w innowacyjny produkt lub usługę; nabywcy odgrywają rolę zarówno współkreatorów, jak i użytkowników aktywnie uczestniczących w procesach ukierunkowanych na postęp i wynalazczość w przedsiębiorstwie;

- etap wprowadzania innowacyjnego produktu lub usługi na rynek (uwzględniający działalność polegającą na przygotowaniu do wdrożenia); użytkownicy stają się testerami produktów i usług, mogą również stanowić tzw. użytkowników końcowych, czyli bezpośrednich odbiorców, dokonujących zakupu testowanego produktu lub usługi.

Chociaż pozyskiwanie informacji od użytkowników jest procesem wymagającym od przedsiębiorstw zaangażowania jego wewnętrznych zasobów oraz środków, to 
wykorzystanie tego źródła wiedzy może pozytywnie oddziaływać na pozycję rynkową przedsiębiorstwa. Dodatkowymi korzyściami z perspektywy przedsiębiorstw jest wzrost postrzeganej przez użytkowników użyteczności i lepsza jakość usług (Baldwin, Hienerth, Von Hippel, 2006; Flowers, Von Hippel, De Jong, Sinozic, 2010). Jednym z zagrożeń dla przedsiębiorstwa otwartego na rynkowe źródła informacji jest większy (niż w przypadku przedsiębiorstw działających w zamkniętym cyklu innowacji) stopień ujawniania pomysłów (Harhoff, Henkel, Von Hippel, 2003). Jest to związane z dzieleniem się zgromadzoną w przedsiębiorstwie wiedzą z innymi uczestnikami rynku oraz ułatwianiem dostępu do informacji, które są ważne dla przedsiębiorstwa.

Znaczenie relacji z użytkownikami w działalności innowacyjnej jest przedmiotem badań nad przedsiębiorstwami turystycznymi (np. Szymańska, 2017), w tym również przedsiębiorstwami hotelarskimi (Sundbo, Orfila-Sintes, Sørensen, 2007). Wyjątkowość hoteli jako podmiotów w badaniach charakteryzujących zjawisko innowacji pochodzących od klienta wynika z cech tych przedsiębiorstw, takich jak: otwarty charakter działalności, duża intensywność i wielorakość relacji z użytkownikami, czas spędzony przez klienta w przedsiębiorstwie, rozproszony i silnie lokalny charakter działalności. Klient jest obecny w przedsiębiorstwie hotelarskim znacznie dłużej niż w innych typach przedsiębiorstw usługowych, co można wykorzystać do pozyskiwania informacji o jego potrzebach i oczekiwaniach. Kolejną cechą, która sprzyja zastosowaniu koncepcji UDI w hotelarstwie, jest kompleksowość i heterogeniczność produktu. Jest on indywidualną wiązką wybranych przez klienta usług, mających spełnić jego potrzeby. Ponadto oczekiwania względem oferty zmieniają się w czasie i różnią się w zależności od motywu przyjazdu. Innowacyjność wynikać może tym samym zarówno z udoskonalenia jednego elementu, jak i złożonego produktu. Z perspektywy przedsiębiorstw hotelarskich koncepcja innowacji pochodzących od klienta jest więc kluczowym filarem wzrostu innowacyjności tego sektora usług.

Dotychczasowe badania dowodzą, że wiedza odgrywa istotną rolę i determinuje sukces rynkowy przedsiębiorstw hotelarskich (Sørensen, 2007; Nieves, Quintana, Osorio, 2014). Poza wiedzą zdobywaną w wyniku prac badawczych oraz dzięki postępowi technicznemu i nowym technologiom, potrzeby rynkowe uznawane są za kluczowe źródło informacji wykorzystywane w procesach innowacyjnych przedsiębiorstw działających w sektorze usług hotelarskich oraz pozostałych przedsiębiorstw świadczących usługi turystyczne (Hall, Williams, 2008). Ponadto w literaturze przedmiotu zwraca się uwagę na zjawisko tzw. customizacji (z ang. customization, czyli oferowanie indywidualnie dopasowanych produktów lub usług), pojawiające się w obszarach, w których rośnie siła nabywcza konsumentów (Hjalager, 2010). Zjawisko to łączy się także z gromadzeniem i przetwarzaniem informacji na temat każdego indywidualnego konsumenta. Badania w sektorze hotelarskim nie rozstrzygają jednak, jaka jest rola relacji z klientami w działalności innowacyjnej. Wyniki niektórych prac potwierdzają, że zaangażowanie klienta i wykorzystanie jego wiedzy zwiększa szanse na powstawanie nowych rozwiązań w usługach hotelarskich (Orfila-Sintes, Mattsson, 2009). Współpraca z klientami została także doceniona w badaniach A. Trigo i X. Vence’a (2012).

Zależność pomiędzy orientacją przedsiębiorstw hotelarskich na klienta a ich innowacyjnością była przedmiotem nielicznych prac badawczych podejmowanych w tym sektorze (Tajeddini, 2010; Tajeddini, Trueman, 2012; Grissemann, Plank, Brunner-Sperdin, 2013). Pierwsze badanie zrealizowane w grupie szwajcarskich hoteli (Tajeddini, 2010) nie potwierdziło statystycznego wpływu relacji z klientami na innowacyjność 
tych obiektów. Udowodniono jednakże, że komunikacja z nabywcami usług wpływa na korzyści finansowe badanych przedsiębiorstw, przekładając się na wzrost sprzedaży oraz rentowności. Wspomniana zależność nie potwierdziła się z kolei w badaniu S. Agarwala, M.K. Erramilli, S.C. Deva (2003) dotyczącym obiektów hotelarskich należących do międzynarodowych sieci oraz w badaniu innowacyjności hoteli działających w regionie Alp (Grissemann, Plank, Brunner-Sperdin, 2013). W ich przypadku priorytetowe traktowanie klienta i relacje z nimi nie miały bezpośredniego wpływu na korzyści finansowe i pozafinansowe przedsiębiorstw, jednak U. Grissemann, A. Plank, A. Brunner-Sperdin (2013) udowodnili pozytywną korelację pomiędzy współpracą z klientami a aktywnością innowacyjną hoteli i poziomem ich innowacyjności, przekładającą się na pozyskanie wielu nabywców.

Kolejne badania K. Tajeddini i M. Trueman (2012) zweryfikowały innowacyjność szwajcarskiego sektora hotelarskiego, potwierdzając pozytywną korelację między innowacyjnością a orientacją na klienta. Co więcej, badania dowiodły, że bardziej innowacyjne są obiekty, które podejmują długoterminowe działania w utrzymywaniu relacji z klientami (Tajeddini, Trueman, 2012).

Relacje z klientami w obiektach hotelarskich były również przedmiotem badań prowadzonych przez M. Ottenbachera (2007). Dowiódł on, że we współpracy z klientami istotną rolę odgrywają pracownicy przedsiębiorstwa, którzy często są pierwszymi odbiorcami informacji pochodzących od klientów. Jak wskazują wyniki badania M. Ottenbachera (2007), efektywność przedsiębiorstwa w obszarze innowacji podnoszą m.in. szkolenia personelu oraz działania umożliwiające zaangażowanie pracowników w procesy innowacyjne. Ponadto z perspektywy rozwoju nowych produktów istotna jest również otwartość kadry kierowniczej na nową wiedzę oraz długoterminową współpracę pracowników z klientami.

W kolejnej części przedstawione zostaną wyniki autorskiego badania prowadzonego wśród przedsiębiorstw hotelarskich w Polsce, które pozwoliło ocenić, w jakim zakresie relacje z użytkownikami są wykorzystywane w działalności innowacyjnej polskich hoteli, oraz w jakim stopniu wpływają na ich innowacyjność.

\section{METODYKA I WYNIKI BADANIA}

Prezentowane dane pochodzą z ogólnopolskiego badania realizowanego w ostatnim kwartale 2015 roku. Zastosowano w nim losowy i warstwowy dobór próby, uwzględniający podział na hotele należące do międzynarodowych sieci oraz hotele działające poza strukturami sieciowymi. Operat badania stanowiła baza teleadresowa Centralnego Wykazu Obiektów Hotelarskich administrowana przez Ministerstwo Sportu i Turystyki. Badaniem objęto 326 hoteli niezależnych, działających poza strukturą międzynarodowych sieci hotelowych, i 74 hotele należące do takich sieci.

Respondentami badania były osoby zarządzające hotelami lub wyznaczeni pracownicy szczebla kierowniczego. W każdym z hoteli zrealizowany został jeden wywiad techniką CAWI lub CATI. Największy odsetek w próbie hoteli niezależnych, działających poza strukturami sieci międzynarodowych, stanowiły małe (do 50 pokoi), trzygwiazdkowe obiekty. Z kolei wśród hoteli sieciowych najsilniejszym ich reprezentantem w próbie były obiekty czterogwiazdkowe, oferujące od 101 do 350 pokoi.

Celem badania było ustalenie, jak bardzo przedsiębiorstwa są otwarte na zaangażowanie klientów w procesy innowacyjne, poprzez umożliwianie im współtworzenia 
oferty lub poprzez wykorzystanie ich wiedzy na innych etapach procesu innowacyjnego. Ponadto zidentyfikowano zależność pomiędzy orientacją na klienta, rozumianą jako podejmowanie działań mających na celu utrzymywanie relacji z klientami a innowacyjnością. Ostatecznie oceniono, czy orientacja przedsiębiorstwa na utrzymywanie relacji z klientami wpływa na innowacyjność przedsiębiorstwa.

W pierwszym etapie procedury badawczej przeanalizowano poziom oraz częstotliwość zaangażowania klientów w procesy innowacyjne przedsiębiorstwa (ryc. 1).

Wyniki badania wskazują, że najczęściej rola klientów w działalności innowacyjnej polega na dzieleniu się z przedsiębiorstwem swoimi pomysłami. Znacznie rzadziej aktywność klientów sprowadza się do testowania oferty przedsiębiorstwa. Co ciekawe, równie często rola klientów jest pasywna, ograniczona jedynie do nabywania usług, co aktywna - polegająca na współtworzeniu z przedsiębiorstwem nowych produktów i usług. P. Christiansson i inni (2008) podkreślają, że osoby korzystające z produktów i usług rzadko są zaangażowane w cały proces innowacji, począwszy od zgłaszania pomysłu po jego realizację.

Poziom zaangażowania klientów w procesy innowacyjne warto porównać z pytaniem o to, kto najczęściej inicjował i opracowywał innowacje (ryc. 2). Z rozkładu odpowiedzi respondentów wynika, że kluczowym źródłem powstawania innowacji w przedsiębiorstwach hotelarskich są pracownicy. W przypadku $40 \%$ badanych obiektów powstają one dzięki kooperacji personelu z klientami, a dla 36\% - stanowią efekt samodzielnych działań pracowników. Ostatecznie wyniki badania potwierdzają kluczową rolę pracowników w kontaktach z klientami, których opinie i informacje są wykorzystywane w działalności innowacyjnej przedsiębiorstw.

Kolejny etap procedury badawczej polegał na oszacowaniu wpływu działań badanych przedsiębiorstw odnoszących się do pozyskiwania informacji od klientów na ich innowacyjność. Działania związane z aktywnością przedsiębiorstwa w zakresie

Ryc. 1. Ocena poziomu zaangażowania klientów w procesy innowacyjne przedsiębiorstwa

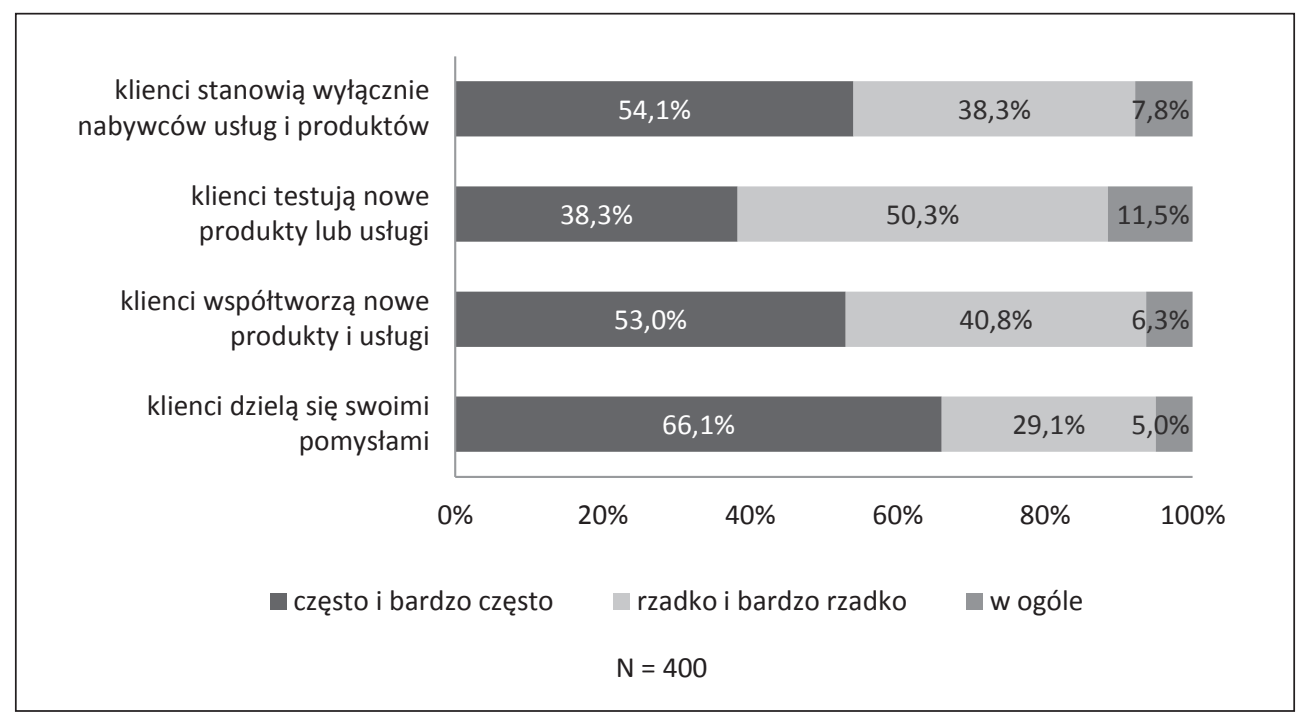

Źródło: opracowanie własne na podstawie wyników badania ilościowego 
Ryc. 2. Najczęściej wskazywane źródło innowacji w przedsiębiorstwach hotelarskich

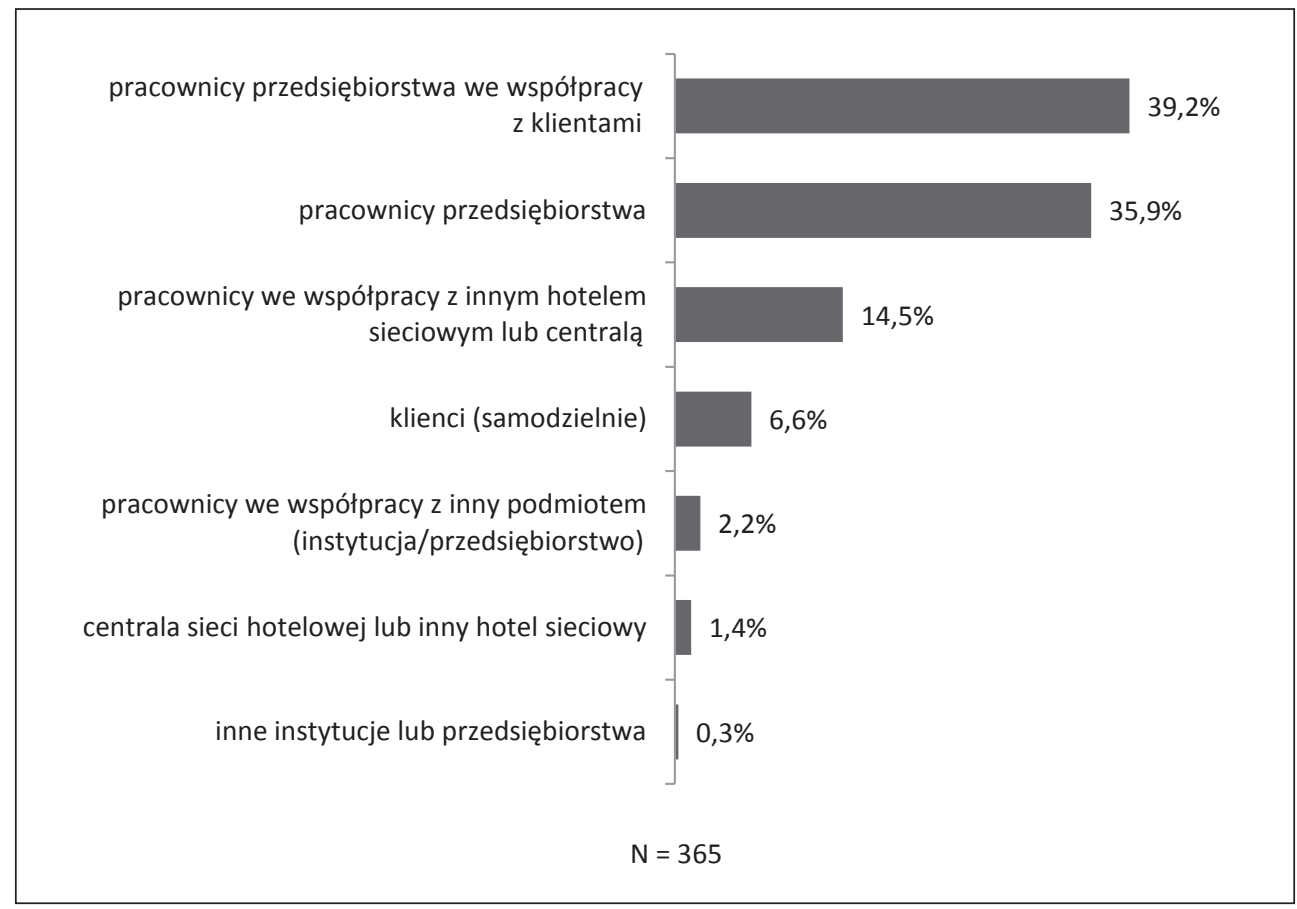

Źródło: opracowanie własne na podstawie wyników badania ilościowego

wsłuchiwania się w potrzeby i oczekiwania gości oraz budowanie relacji z nimi zdefiniowano w postaci zmiennej niezależnej - orientacja na klienta. Jej wartość oszacowano za pomocą modelowania strukturalnego, wykorzystując metodę największej wiarygodności (ML). Na orientację na klienta złożyły się zmienne odnoszące się do sposobów pozyskiwania informacji od klientów oraz zmienna kodująca istotność informacji pochodzących od klientów.

Z kolei zmienną zależną, innowacyjność przedsiębiorstwa, oszacowano na podstawie pytania o rodzaj innowacji wprowadzonych w ostatnich trzech latach działalności badanych przedsiębiorstw (2012-2014). Wyniki badania dowiodły, że większość przedsiębiorstw hotelarskich objętych badaniem wdrożyło innowacje do swojej działalności $(91,2 \%, \mathrm{~N}=365)$.

W celu estymacji zależności między zmienną zależną - orientacja na klienta, a zmienną niezależną - innowacyjność, posłużono się modelem regresji jednozmiennowej. Dzięki temu określona została siła analizowanej zależności.

Wyniki analizy regresji przedstawione w tabeli 1 dowodzą, że orientacja na klienta ma bardzo silny wpływ na innowacyjność przedsiębiorstw hotelarskich objętych badaniem ( $\beta=0,877$; zależność istotna statystycznie). Uzyskana standaryzowana wartość parametru wskazuje, że wzrost orientacji przedsiębiorstwa na klienta o jedno odchylenie standardowe spowoduje wzrost zmiennej zależnej innowacyjność o 0,877 jej odchylenia standardowego. Ponadto zmienna niezależna objaśnia innowacyjność w 77\%, o czym świadczy wartość współczynnika determinacji wynosząca 0,768. 
Tab. 1. Wpływ zmiennej niezależnej orientacja na klienta na zmienną zależną innowacyjność - wyniki analizy regresji

\begin{tabular}{|l|c|c|c|c|c|}
\hline \multirow{2}{*}{ Model } & \multicolumn{2}{|c|}{ Wartości niestandaryzowane } & $\begin{array}{c}\text { Wartości } \\
\text { standaryzowane }\end{array}$ & \multirow{2}{*}{ Statystyka t } & Istotność \\
\cline { 2 - 5 } & $\mathrm{B}$ & $\begin{array}{c}\text { błąd } \\
\text { standardowy }\end{array}$ & $\beta$ &, 001 &, 999 \\
\hline Stała & $7,019 \mathrm{E}-06$ &, 005 & & 36,357 &, 000 \\
\hline Orientacja na klienta &, 581 &, 016 &, 877 & 37 \\
\hline
\end{tabular}

Analiza: metoda wprowadzania. Model dopasowany do danych $F(1,398)=1321,85$, p < 0,01. Statystyki współliniowości VIF = 1, Statystyka Durbina-Watsona: 1,888.

Źródło: opracowanie własne na podstawie wyników badania ilościowego

Analiza współczynników korelacji Pearsona wskazuje, że między poszczególnymi zmiennymi odnoszącymi się do sposobów komunikacji przedsiębiorstwa z klientami oraz do oceny znaczenia informacji pochodzących z tego źródła występują istotne statystycznie dodatnie współzależności (tab. 2).

Tab. 2. Współczynniki korelacji Pearsona

\begin{tabular}{|l|l|}
\hline \multicolumn{1}{|c|}{ Zmienne } & \multicolumn{1}{c|}{ Orientacja na klienta } \\
\hline Media społecznościowe & $0,348^{* *}$ \\
\hline Strona internetowa & $0,229^{* *}$ \\
\hline Ankieta hotelowa & $0,443^{* *}$ \\
\hline Badania marketingowe & $0,695^{* *}$ \\
\hline Kontakty osobiste pracowników w trakcie obsługi & $0,746^{* *}$ \\
\hline Obserwacja klientów w trakcie obsługi & $0,536^{* *}$ \\
\hline Indywidualne spotkania z klientami & $0,765^{* *}$ \\
\hline Księga gości & $0,474^{* *}$ \\
\hline Istotność informacji od klientów & $0,154^{* *}$ \\
\hline
\end{tabular}

** Korelacja istotna na poziomie 0,01 (dwustronnie).

Źródło: opracowanie własne na podstawie wyników badania ilościowego

Dane przedstawione w tabeli 2 potwierdzają, że najsilniejsze współzależności występują w przypadku przedsiębiorstw hotelarskich, które nawiązują relacje z klientami dzięki indywidualnym spotkaniom z nimi, osobistym kontaktom pracowników w trakcie obsługi oraz informacjom pozyskiwanym w badaniach marketingowych. W przypadku pozostałych zmiennych wartości współczynników osiągają niższe wartości, tym samym siłę badanych współzależności oceniono jako przeciętną lub słabą.

\section{WNIOSKI}

Relacje z klientami zawsze miały kluczowe znaczenie w turystyce (Hjalager, Nordin, 2011). Jak wynika z przeprowadzonego badania, aktywne zaangażowanie w utrzymywanie relacji z użytkownikami ma znaczenie dla kształtowania innowacyjności przedsiębiorstw hotelarskich w Polsce. Niezależnie, czy przybiera ono najbardziej dojrzałą 
formę, którą określić można jako innowacje pochodzące od klienta (koncepcja user-driven innovation), czy ma mniej rozwiniętą postać, wsłuchiwanie się w oczekiwania nabywców i śledzenie rynkowych trendów jest fundamentem innowacyjnej aktywności przedsiębiorstw.

Przedstawione wyniki badania dowodzą, że hotele, które charakteryzuje wysoka orientacja na klientów, cechuje też wyższy poziom innowacyjności. Jest to zgodne z wynikami innych prac badawczych, które prowadzili m.in. K. Tajeddini i M. Trueman (2012) oraz U. Grissemann, A. Plank, A. Brunner-Sperdin (2013). Ponadto wpływ wiedzy klientów na innowacyjność ma charakter pośredni i odbywa się przy ważnym udziale pracowników. W badanych przedsiębiorstwach klienci dzielą się swoimi pomysłami, które dzięki wykwalifikowanemu personelowi stają się źródłem wdrażanych zmian. W mniejszym stopniu klienci mają bezpośredni wpływ na powstawanie innowacji poprzez tworzenie nowych produktów czy nawet ich testowanie. Badania P. Christianssona i innych (2008) wskazują, że użytkownicy rzadko angażowani są w cały proces innowacji. Przedsiębiorstwa hotelarskie, mimo że ich cechy sprzyjają szerokiemu wykorzystaniu wiedzy pochodzącej od klienta, znajdują się na wczesnym etapie procesu adaptacji koncepcji innowacji pochodzących od klienta. Jednakże warto podkreślić, że wykorzystanie nawet wybranych elementów koncepcji UDI stwarza przedsiębiorstwom szansę na zmiany w ofercie, zwiększa zaangażowanie w obserwowanie rynku i zachowań konkurentów, pozwala reagować na zmiany w popycie (Feng, Sun, Zhang, 2010). Zaprezentowane wyniki są zgodne z pracami M. Ottenbachera (2007), z których wynika, że to pracownicy sektora hotelarskiego pełnią funkcję depozytariuszy wiedzy pochodzącej od klientów. Poprawa skuteczności działalności innowacyjnej opartej na relacjach z klientami wymaga więc tworzenia kultury organizacyjnej premiującej gromadzenie i wykorzystanie wiedzy klienta, a także systematycznego podejścia, opartego na praktykach wpisanych na stałe w zakres obowiązków pracowników.

Dalsze badania powinny koncentrować się wokół problematyki wsparcia przedsiębiorców w działalności innowacyjnej. Za szczególnie interesujące uznać należy zbadanie uwarunkowań innowacyjności opartej na relacjach, a przede wszystkim tych związanych z zasobami ludzkimi oraz wykorzystaniem nowych technologii. Warto także przeprowadzić pogłębioną analizę zależności pomiędzy orientacją przedsiębiorstw na klienta wykorzystywaną w celu podnoszenia innowacyjności a osiąganymi rezultatami ekonomicznymi. Ponadto można wskazać dwa kierunki rozwoju koncepcji innowacji opartych na relacjach z klientami, wyodrębnione na podstawie sposobu gromadzenia informacji oraz ich skuteczności. Z jednej strony, pozyskiwanie informacji tradycyjną drogą, czyli z wykorzystaniem pogłębionych badań marketingowych. Pozwoli to na projektowanie kluczowych komponentów usługi i dokonywanie istotnych z punktu widzenia przedsiębiorstwa zmian innowacyjnych. Z drugiej strony, konieczne jest wsłuchiwanie się w oczekiwania nabywcy, poprzez regularne obserwacje prowadzone przez personel lub dzięki wykorzystaniu nowych kanałów komunikacji, np. mediów społecznościowych lub portali typu OTA (internetowych biur podróży). Dzięki temu możliwe będzie pozyskanie niezwykle bogatego materiału empirycznego wywodzącego się z „głosu konsumenta”, który pozwoli na dokonywanie często drobnych, ale niezwykle pożądanych przez gości zmian. Podejście do działalności innowacyjnej oparte na relacjach z klientami może stanowić więc jeden z kluczowych czynników sukcesu rynkowego firmy i przyczynić się do uzyskania trwałej przewagi konkurencyjnej. 


\section{Literatura \\ References}

Agarwal, S., Erramilli, M.K., Dev, S.C. (2003). Market orientation and performance in service firms: role of innovation. Journal of Services Marketing, 17(1), 68-82.

Baldwin, C., Hienerth, C., Von Hippel, E. (2006). How User Innovations Become Commercial Products: A Theoretical Investigation and Case Study. Research Policy, 35(9), 1291-1313.

Christiansson, P, Sørensen, K.B., Rødtness, M., Abrahamsen, M., Riemnann, L.O., Alsdorf, M. (2008). User-Driven Innovation in the Building Process. Tsinghua\& Technology, 13(1), 248-254.

Feng, T., Sun, L., Zhang, Y. (2010). The effects of customer and supplier involvement on competitive advantage: An empirical study in China. Industrial Marketing Management, 39(8), 1384-1394.

Flowers, S., Von Hippel, E., De Jong, J., Sinozic, T. (2010). Measuring user innovation in the UK. The importance of product creation by users. NESTA.

Fuller, J., Matzler, K. (2007). Virtual product experience and customer participation - A chance for customer-centered, really new products. Technovation, 27(6-7), 378-387.

Grissemann, U., Plank, A., Brunner-Sperdin, A. (2013). Enhancing business performance of hotels: the role of innovation and customer orientation. International Journal of Hospitality Management, 33, 347-356.

Hall, C.M., Williams, A.M. (2008). Tourism and innovation. London: Routledge.

Harhoff, D., Henkel, J., Von Hippel, E. (2003). Profiting from voluntary information spillovers: How users benefit by freely revealing their innovations. Research Policy, 32, 1753-1769.

Hjalager, A.M. (2010). A review of innovation research in tourism. Tourism Management, 31(1), $1-12$.

Hjalager, A.M., Nordin, S. (2011). User-Driven Innovation in Tourism - A Review of Methodologies. Journal of Quality Assurance in Hospitality \& Tourism, 12(4), 289-315.

Nieves, J., Quintana, A., Osorio, J. (2014). Knowledge-based resources and innovation in the hotel industry. International Journal of Hospitality Management, 38, 65-73.

OECD (1996) (2017, 30 listopada). The Knowledge-Based Economy. Paris: OECD. Pozyskano z http://www.oecd.org/sti/sci-tech/1913021.pdf

O'Hern, M., Rindfleisch, A. (2008). Customer Co-creation: A Typology and Research Agenda. Innovation Thoughts on Innovation from the Wisconsin School of Business, Working Paper, 4.

Orfila-Sintes, F., Mattsson, J. (2009). Innovation behavior in the hotel industry. Omega, 37(2), 380-394.

Ottenbacher, M. (2007). Innovation Management in the Hospitality Industry: Different Strategies for Achieving Success. Journal of hospitality and Tourism Research, 31(4), 431-454.

Piller, F., Ihl, Ch. (2009). Open Innovation with Customers. Foundations, Competences and International Trends. Technology and Innovation Management Group. Germany: RWTH Aachen University.

Salter, A., Laursen, K. (2006). Open for innovation: The role of openness in explaining innovation performance among UK manufacturing firms. Strategic Management Journal, 27(2), 131-150.

Sørensen, F. (2007). The geographies of social networks and innovation in tourism. Tourism Geographies, 9(1), 22-48.

Sundbo, J., Orfila-Sintes, F., Sørensen, F. (2007). The innovative behavior of tourism firms Comparative studies of Denmark and Spain. Research Policy, 36(1), 88-106.

Szymańska, E. (2017). User-Driven Innovation - the Concept and Research Results. Procedia Engineering, 182, 694-700.

Tajeddini, K. (2010). Effect of customer orientation and entrepreneurial orientation on innovativeness: Evidence from the hotel industry in Switzerland. Tourism Management, 31(2), 221-231.

Tajeddini, K., Trueman, M. (2012). Managing Swiss hospitality: how cultural antecedents of innovation and customer - oriented value systems can influence performance in the hotel industry. International Journal of Hospitality Management, 31, 1119-1129. 
Tether, B.S. (2002). Who co-operates for innovation, and why. An empirical analysis. Research Policy, 31, 947-967.

Trigo, A., Vence, X. (2012). Scope and patterns of innovation cooperation in Spanish service enterprises. Research Policy, 41(3), 602-613.

Von Hippel, E. (1976). The Dominant Role of Users in the Scientific Instrument Innovation Process. Research Policy, 5(3), 212-239.

Von Hippel, E. (1988). The Sources of Innovation. New York: Oxford University Press.

Von Hippel, E. (1990). Predicting the Source of Commercially Valuable User Innovation Via Lead Users. Advances in Telecommunication Management, 1(1), 131-145.

Von Hippel, E. (2005). Democratizing Innovation. Cambridge, Massachusetts: Massachusetts Institute of Technology.

Wise, E., Høgenhaven, C. (2008). User-Driven Innovation. Context and Cases in the Nordic Region. Oslo: Nordic Innovation Centre.

Barbara Kowalczyk, dr, główny specjalista badawczy w Laboratorium Analiz Statystycznych i Ewaluacji w Ośrodku Przetwarzania Informacji - Państwowym Instytucie Badawczym. W 2017 roku obroniła rozprawę doktorską poświęconą wpływowi relacji z użytkownikami na innowacyjność przedsiębiorstw hotelarskich. Ukończyła Uniwersytet Ekonomiczny w Poznaniu. Jej zainteresowania badawcze skupiają się wokół problematyki innowacyjności, działalności badawczo-rozwojowej, sektora szkolnictwa wyższego. Doświadczenie zdobywała, uczestnicząc w kilkunastu projektach badawczych, realizowanych m.in. dla Ministerstwa Nauki i Szkolnictwa Wyższego, Narodowego Centrum Badań i Rozwoju, Komisji Europejskiej. Jest autorem oraz współautorem kilkunastu publikacji i artykułów z tematyki innowacyjności, przedsiębiorczości, sektora B+R.

Barbara Kowalczyk, Ph.D., is Chief Researcher at the Laboratory of Statistical Analysis and Evaluation of the National Information Processing Institute. She has finished her Ph.D. studies in 2017 with a doctoral thesis on the influence of relationship with the users on innovativeness of hotel companies. She has graduated from the Poznań University of Economics and Business. Her interests are focused on innovativeness, R\&D actions, higher education sector. She has participated in several research and commercial projects, financed by the Ministry of Science and Higher Education, The National Center for Research and Development, European Commission. She is an author or co-author of several books and articles on innovation, entrepreneurship, R\&D sector.

\section{Adres/address:}

Ośrodek Przetwarzania Informacji - Państwowy Instytut Badawczy

Laboratorium Analiz Statystycznych i Ewaluacji

al. Niepodległości 188b, 00-608 Warszawa, Polska

e-mail: bkowalczyk@opi.org.pl

Marcin Olszewski, dr, adiunkt w Katedrze Turystyki na Wydziale Gospodarki Międzynarodowej Uniwersytetu Ekonomicznego w Poznaniu. W 2011 roku obronił rozprawę doktorską poświęconą zarządzaniu wiedzą w procesie konkurowania przez jakość na rynku hotelarskim. Jego zainteresowania badawcze obejmują problematykę współpracy uczelni z przedsiębiorstwami turystycznymi, zarządzania wiedzą, transferu wiedzy, konkurencyjności gospodarki turystycznej. Brał udział w kilku krajowych i międzynarodowych projektach badawczych dotyczących gospodarki turystycznej ( $w$ tym finansowanych przez Ministerstwo Nauki i Szkolnictwa Wyższego i Narodowe Centrum Nauki). Jest autorem lub współautorem ponad 50 artykułów (rozdziałów w monografiach naukowych, artykułów w czasopismach naukowych oraz prac w materiałach konferencyjnych).

Marcin Olszewski, Ph.D., is an Assistant Professor at the Department of Tourism, Faculty of International Business and Economics at the Poznan University of Economics and Business, Poland. He has finished his Ph.D. studies in 2011 with a doctoral thesis on knowledge management in hospitality industry. His areas of research include university-industry collaboration in tourism industry, knowledge management, tourism industry competitiveness, economics of tourism enterprise. He has participated in several research projects on tourism and hospitality industry (including those financed by the Ministry of Science and Higher Education and the National Science Center). He is an author or co-author of more than 50 papers (chapters in monographs, articles in journals and conference papers). 
Adres/address:

Uniwersytet Ekonomiczny w Poznaniu

Wydział Gospodarki Międzynarodowej

Katedra Turystyki

al. Niepodległości 10, 61-875 Poznań, Polska

e-mail: marcin.olszewski@ue.poznan.pl 